\title{
Comparison of loop-mediated isothermal amplification and conventional PCR tests for diagnosis of common Brucella species
}

\author{
Ali Moeini-Zanjani ${ }^{1}$, Abazar Pournajaf ${ }^{1,2}$, Elaheh Ferdosi-Shahandashti ${ }^{2,3}$, Mehrdad Gholami ${ }^{4}$, \\ Faramarz Masjedian ${ }^{5}$, Soraya Khafri ${ }^{6}$ and Ramazan Rajabnia ${ }^{1,2^{*}}$
}

\begin{abstract}
Objective: Rapid, reliable, and affordable detection of Brucella species via the molecular methods remains a challenge. In recent years, loop-mediated isothermal amplification (LAMP) is a functional nucleic acid amplification technique offering a substitute to polymerase chain reaction (PCR). So, we compared the LAMP assay with the conventional PCR for the identification of common Brucella species in Iran. In this study, LAMP assay was comprehensively evaluated against the common PCR method. A group of specific LAMP primers were used to amplify a highly specific fragment from the sequence of the Brucella abortus, bcsp31 gene. Sensitivity and specificity values of tests were done with a set of 78 (50 Brucella and 28 non-Brucella) strains.

Results: A dilution series of $B$. abortus DNA indicated that the LAMP reaction could reliably detect $10(\mathrm{fg} / \mu \mathrm{l})$ DNA target copies per reaction within 36 min, which is 10 times greater than the PCR assay. In summary, we conclude that LAMP assay provide accurate and fast test results to identify of common Brucella species in low-complexity labs, mainly in low and lower middle income countries.
\end{abstract}

Keyword: Brucellosis, Diagnosis, PCR, LAMP

\section{Introduction}

Brucella species are small, coccobacilli, Gram-negative, absolute aerobic and non-moving bacteria which causes undulant fever in humans and leads to abortion and infertility in animals [1]. Brucella can be transmitted to humans through direct contact with animals or their products that are contaminated with these bacteria [2]. Brucella genus has six species that cannot be distinguished from each other due to the close phenotypic and antigenic similarities with conventional microbiological methods $[3,4]$. From these six species, $[B$. abortus, $B$. melitensis, B. suis and B. canis] generally causes human

\footnotetext{
*Correspondence: ramazan69@yahoo.com

${ }^{2}$ Infectious Diseases and Tropical Medicine Research Center, Babol

University of Medical Sciences, Babol, Iran

Full list of author information is available at the end of the article
}

infection [5]. About half a million cases of human brucellosis are reported annually which is estimated to be $10-25 \%$ less than the real number of the 1997 world health organization (WHO) report [6]. The centers for disease control and prevention strategic planning group as listed B. abortus, B. melitensis, B. suis as category B biothreat agents $[5,7]$. There are currently three main methods for the identification of brucellosis [8]. Overall, in human brucellosis, isolation of the bacterium by blood culture is considered as the gold standard for laboratory diagnosis, but the procedure is time consuming $[9,10]$, and has a low sensitivity in the range of $15-70 \%$ depending on the bacterial species and infectious phase [11]. On the other hand, this method, due to class III biosafety of Brucella is very dangerous and pollutant for laboratory personnel $[12,13]$. Serological examinations are relatively fast to accomplish; however, their results 
are not satisfactory. One such example is that they have low sensitivity, due to the structural similarity of Brucella lipopolysaccharide (LPS) with other Gram-negative bacteria [3, 14]. Nucleic acid amplification tests (NAATs), such as the polymerase chain reaction (PCR) with high sensitivity and specificity have been developed to detect Brucella DNA in human specimens $[15,16,17]$. PCR and other molecular techniques have their own disadvantages; for example; most molecular techniques require a thermal cycler machine, which is not feasible for laboratories in deprived areas such as rural laboratories [18]. The LAMP system has been developed as a new diagnostic technique which could replicate the target DNA without the need for a thermal cycler. In this method with unique Bst DNA polymerase large fragment characteristics such as autoclaving and strand displacement, it became possible to eliminate the thermal cycler and replaced it with thermal block or bain-marie, it was also possible to see the results by visual inspection. because of turbidity generated in positive samples $[19,20]$. This technique has already been evaluated and tested to identify and detect different bacteria and viruses and its high sensitivity and specificity have been proven [21-24]. So, we compared the LAMP assay with the conventional PCR method for the identification of common Brucella species in Iran.

\section{Main text \\ Methods}

\section{Bacterial strains and sample processing}

In this study, to standardize the LAMP protocols, $78 \mathrm{bac}-$ terial strains including 50 Brucella and 28 non-Brucella strains were analyzed (details mentioned in Table 1).
Brucella strains was cultured in a BSL2 laboratory on $5 \%$ sheep blood agar medium (Merck, Germany) and on Brucella agar medium with 5\% sheep blood (Merck, Germany) under $5 \% \mathrm{CO}_{2}$ in an-anaerobic jar for $36 \mathrm{~h}$ at $37^{\circ} \mathrm{C}$. Other non-Brucella strains were cultured in trypticase soy agar (Merck, Germany) and deleted replasing supplemented with $5 \%$ sheep blood agar for $18 \mathrm{~h}$ at $37^{\circ} \mathrm{C}$.

\section{DNA extraction procedures}

Briefly, a loopful of colonies were aseptically collected from the plates and suspended in $5 \mathrm{~mL}$ pf phosphate buffered saline (PBS) until its opacity reaches \#2 McFarland standard turbidity. After vortexing, genomic DNA of strains were extracted with the High Pure PCR Template Preparation Kit (Roche, Germany), according to the manufacturer's instructions. The absorbance ratio (A260/280) is used to evaluate the purity of DNA.

\section{Primers}

We tried to detect the same gene in each two techniques for minimization of the variables, so the $b c s p 31$ gene selected for the detection in both techniques. The primers sequences used for LAMP and PCR was shown in Table2.

\section{Conventional PCR}

The PCR assay was carried out as previously described by Baily et al. [15]. Amplification targeting bcsp 31 gene was performed in a Techne TC-512 thermal cycler (Eppendorf, Hamburg, Germany) according to the conditions mentioned in Table 3.

Table 1 Bacterial strains used in this study and the results of PCR and LAMP amplification

\begin{tabular}{|c|c|c|c|c|c|}
\hline Strains & Species (biovar) & No. of strains & Source & LAMP results & PCR results \\
\hline B. abortus & 1 & 1 & S99 (Reference) & + & + \\
\hline B. abortus & 1 & 1 & S19 (vaccine strain) & + & + \\
\hline B. abortus & 2 & 1 & Clinical isolate & + & + \\
\hline B. abortus & 3 & 18 & Clinical isolate & + & + \\
\hline B. abortus & 3 & 7 & Animal isolate & + & + \\
\hline B. melitensis & 1 & 1 & 16 M (ATCC23456) & + & + \\
\hline B. melitensis & 1 & 13 & Clinical isolate & + & + \\
\hline B. melitensis & 1 & 8 & Animal isolate & + & + \\
\hline Escherichia coli & O157:H7 & 4 & Clinical isolate & - & - \\
\hline Staphylococcus aureus & & 4 & Clinical isolate & - & - \\
\hline Vibrio cholerae & $\mathrm{O} 1$ & 4 & Clinical isolate & - & - \\
\hline Klebsiella pneumoniae & & 4 & Clinical isolate & - & - \\
\hline Acinetobacter baumannii & & 4 & Clinical isolate & - & - \\
\hline Pseudomonas & & 4 & Clinical isolate & - & - \\
\hline Shigella flexineri & & 4 & Clinical isolate & - & - \\
\hline
\end{tabular}


Table 2 Sequences of primers used for LAMP and PCR assay

\begin{tabular}{|c|c|c|c|c|}
\hline \multicolumn{3}{|c|}{ Assay Primer Sequence } & \multicolumn{2}{|c|}{$\begin{array}{l}\text { Amplicon Reference } \\
\text { size (bp) }\end{array}$} \\
\hline \multirow[t]{6}{*}{ LAMP } & F3 & 5'-GCTTTACGCAGTCAGACGT-3' & 189 & {$[25]$} \\
\hline & B3 & 5'-GCTCATCCAGCGAAACGC-3' & & \\
\hline & FIP & $\begin{array}{l}\text { 5'-AGGCGCAAATCTTCCACCTTG } \\
\text { CGCCTATTGGGCCTATAACGG-3' }\end{array}$ & & \\
\hline & BIP & $\begin{array}{l}\text { 5'-GGCGACGCTTTACCCGGAAAT } \\
\text { TCAGGTCTGCGACCGAT-3' }\end{array}$ & & \\
\hline & LF & 5'-CCTTGCCATCATAAAGGCC-3' & & \\
\hline & LB & 5'-CGTAAGGATGCAAACATCAA-3' & & \\
\hline \multirow[t]{2}{*}{ PCR } & B4 & 5'-TGGCTCGGTTGCCAATATCAA-3' & 223 & {$[15]$} \\
\hline & B5 & 5'-CGCGCTTGCCTTTCAGGTCTG-3' & & \\
\hline
\end{tabular}

Table 3 PCR condition for bcsp31 template

\begin{tabular}{lll}
\hline Feature & Temperature $\left({ }^{\circ} \mathbf{C}\right)$ & Time \\
\hline Gene $($ bcsp31) & & \\
Initial denaturation & 95 & $5 \mathrm{~min}$ \\
Denaturation & 95 & $60 \mathrm{~s}$ \\
Annealing & 65 & $30 \mathrm{~s}$ \\
Extension & 72 & $60 \mathrm{~s}$ \\
Final extension & 72 & $6 \mathrm{~min}$ \\
Cycle & 35 & - \\
\hline
\end{tabular}

\section{LAMP reaction optimization}

We used six primers for LAMP assay in this study, LAMP outer primers (F3 and B3), forward inner primer (FIP) and backward inner primer (BIP), which identify four different fragments on the DNA target sequence, and two loop primers (LF and LB) to increase proliferation speed. Also, modifying concentration of reaction components and conditions such as reaction time (20-50 min), amplification temperatures $\left(61-67{ }^{\circ} \mathrm{C}\right)$, concentration of dNTPs (0 to $2 \mathrm{mM}), \mathrm{MgSO} 4(0-6.4 \mathrm{mM})$ and Bst polymerase (2-12 Unit) were chosen to assist in optimizing LAMP procedure in targeting the bcsp31 gene. The optimized reaction mixture contained $5 \mathrm{pmol}^{-1}$ each of outer primers (F3 and B3), $40 \mathrm{pmol}^{-1}$ each of inner primers (FIP and BIP), $20 \mathrm{pmol}^{-1}$ each of loop primers (LF and LB), $1.4 \mathrm{mmol} \mathrm{l}^{-1}$ each deoxynucleoside triphosphates, $0.8 \mathrm{~mol} \mathrm{l}^{-1}$ betain (Sigma, B0300,St. Louis, USA), $20 \mathrm{mmol} \mathrm{l}^{-1}$ Tris-HCl, $10 \mathrm{mmol} \mathrm{l}^{-1}$ (NH4)2SO4, $10 \mathrm{mmol} \mathrm{l}^{-1} \mathrm{KCl}, 8 \mathrm{mmol} \mathrm{l}^{-1} \mathrm{MgSO} 4,0.1 \%$ Triton $\mathrm{X}-100,8$ units of Bst polymerase (New EnglandBiolabs, M0275S, Beverly, USA) and $2 \mu$ lof genomic DNA. Before adding the Bst DNA polymerase, reaction mixture was heated up at $95{ }^{\circ} \mathrm{C}$ for $5 \mathrm{~min}$ in a Thermoblock heat system, and then cooled on ice for $10 \mathrm{~min}$ to provide an appropriate environment for adding Bst. Subsequently, the mixture was incubated at $63{ }^{\circ} \mathrm{C}$ for $35 \mathrm{~min}$ and then, tubes heated at $95^{\circ} \mathrm{C}$ for 2 min to stop the reaction. Five microliters of the product were subjected to $2 \%$ agarose gel electrophoresis.

\section{Results}

All the 50 strains of 4 serotypes of Brucella were shown to be positive by LAMP.

\section{Conventional PCR}

The PCR was performed on 78 species, and a $223 \mathrm{bp}$ bands was observed in all of Brucella spp, on 1.5\% agarose gel. Whereas, no band was seen in other species. The sensitivity and specificity of the primers used in this study have been evaluated by Baily et al. [15]. The detection limit for the PCR assay in the mentioned conditions was $100 \mathrm{fg}$.

\section{Establishment of BCSP31 LAMP and product confirmation}

In this research, we tried our best to minimize the Brucella DNA amplification time in the LAMP assay. So, in deprived areas of Iran, laboratories can measure human or animal contamination in the shortest time with the protocol described in this study. By changing the LAMP assay reaction [termination step protocol from $80{ }^{\circ} \mathrm{C}$ in $5 \mathrm{~min}$ to $95^{\circ} \mathrm{C}$ in $2 \mathrm{~min}$ ] we obtained similar results. Thus we replaced the new modified protocol with the general protocol. To set up and optimization, we used B. melitensis $16 \mathrm{M}$ (ATCC 23456) DNA as template. The LAMP assay successfully amplified the target ( $b c s p 31$ gene) at $63^{\circ} \mathrm{C}$ in $35 \mathrm{~min}$. The well-defined bands patterns, which is a trait of the LAMP reaction and shows the forming DNA stem-loop with inverted repeats of the target sequence [19] was checked using gel electrophoresis method.

\section{Sensitivity of LAMP reaction}

After adjusting the best conditions for the LAMP reaction, the lower detection limit of the LAMP was measured using tenfold serial dilution (initial concentration of $10 \mathrm{ng}$ ) of the DNA samples for $b c s p 31$ gene. Ladder-like pattern on $2 \%$ agarose gel was identified by target DNA of as low as $10 \mathrm{fg}$. Also, sensitivity of minimal detectable rate of LAMP test in compare with PCR is shown in Additional file 1: Figure S1. As shown in the figure, the minimal detectable rate of the LAMP test is $10 \mathrm{fg} / \mu \mathrm{l}$. Therefore, it can be concluded that the minimal detectable rate of LAMP test is 10-times higher than PCR and can be detect a less amount of bacterial genome in the sample. So, LAMP test is more sensitive than PCR. 


\section{Naked-eye detection of positive bcsp31 LAMP amplification} Under situations where detection and urgent care requires rapid response, it is greatly favorable for specify all positive samples as soon as possible. This is one of the advantages of the LAMP assay versus PCR. To achieve this important, the products inside the $0.2 \mathrm{~mL}$ microtubes were placed under white light and the turbidity caused by magnesium pyrophosphate $\left(\mathrm{Mg}_{2} \mathrm{P}_{2} \mathrm{O}_{7}\right)$ in positive samples was observed with the naked eye. Products were also observed by adding 1 to 100 diluted fluorescent detection reagent (SYBR Green I, S9430, Sigma-Aldrich, Germany) under normal, and UV light. There was no difference between the LAMP results detected by fluorescence and turbidity.

\section{Assay specificity through several types of bacterial spp}

To assess the specificity of the LAMP reaction, all 78 bacterial strains were tested by $b c s p 31$ gene-based LAMP assay. The results of this assay are shown in Table 1; the test result for non-Brucella species was negative. Our results showed that the P-1 primer set successfully and specifically amplified bcsp31 gene of Brucella species in vaccine strains, clinical and animal isolates. Whereas other non-Brucella strains did not show any turbidity, fluorescent and any bands on the agarose gel electrophoresis under equal conditions.

\section{Discussion}

This is the primary description on the employment of LAMP to the identification of common species of Brucella based on the bcsp31 gene in Iran. Brucellosis remains a neglected illness in the developing countries. Due to the high prevalence of Brucellosis early diagnosis in conjugation with timely medical intervention is necessary to prevention and control of the infectious disease [26]. The Rose Bengal test (RBT) as a easy method for the identification of specific antibodies against Brucella. However, their fruitfulness is restricted via elevated frequencies of Brucella-specific antibody titer in highbrucellosis burden countries and it low sensitivity at acute phase of disease [27, 28]. Furthermore, the growth of Brucella spp. is time consuming and complex, subsequently bacteriological culture and microscopic examination are cumbersome and difficult [29]. Our major purpose of this work was to assess and compare the diagnostic capabilities of two different molecular detection methods, i.e. LAMP and PCR techniques and to find out whether the LAMP technique is a good alternative to the PCR. We used direct culture test as the "Gold standard" for the preparation of fresh DNA and the uniformization of the terms of the techniques. The LAMP assay is advantageous in compare to the PCR, because of its feasible, easy construction, quick answer and visual recognition. Its simplicity and using low-cost equipment, including laboratory water bath that prepare a stable heat of $63{ }^{\circ} \mathrm{C}$ is acceptable for the test. Compared to the PCR, the LAMP results is straightly observable with the unaided eye negating the necessity for electrophoretic investigation [19]. Moreover, the LAMP assay unlike other molecular techniques does not require special and expensive devices such as thermal cycler and can be performed in low-budget labs in deprived areas, which there is a probability of an outbreak or expose to brucellosis. Characteristics evaluated for the comparison of two techniques in order to overcome one over another in the studies includes the duration of the amplification, the sensitivity, specificity of the technique and the limit of detection. The PCR technique lasted approximately $90 \mathrm{~min}$ and $100 \mathrm{fg}$ of Brucella DNA was successfully completed. In addition, non-specific responses to multiple negative controls were not observed. In the LAMP assay, $10 \mathrm{fg}$ of Brucella DNA was favorably amplified during $35 \mathrm{~min}$ and, the primers used did not have any non-specific reaction to bacterial DNA that was used as negative controls. In comparison of these two assays, the PCR took about $90 \mathrm{~min}$, while the Brucella LAMP can be finished within $35 \mathrm{~min}$ also according to the limit of detection in two assays the sensitivity of the LAMP assay was 10 times higher to that of PCR. About the specificity of the two techniques, each of the two techniques does not have any nonspecific reaction with multiple negative controls and their specificity was almost equal. The Brucella LAMP technique examined in the work is a quick, highly specific and sensitive method that can be substituted for PCR assays in the low-budget labs of Iran and are able to identify native strains of Brucella in Iran. This is a suitable system for peripheral laboratories to diagnosis and investigation of human brucellosis in endemic setting.

\section{Limitations}

The assay should be evaluated using blood or other clinical specimens from infected patients.

\section{Supplementary information}

Supplementary information accompanies this paper at https://doi. org/10.1186/s13104-020-05377-8.

Additional file 1: Figure S1. Sensitivity of minimal detectable rate of LAMP test in compare with PCR. (A); the minimal detectable rate of Brucella DNA in PCR technique is $100 \mathrm{fg} / \mu \mathrm{l}$, (B); detection of $10 \mathrm{fg} / \mu \mathrm{l}$ bacteria genome in LAMP test. M; 100 bp DNA size marker (SinaClon Bioscience Co, Iran), C- (negative control). 


\section{Abbreviations}

LAMP: Loop-mediated isothermal amplification; PCR: Polymerase chain reaction; WHO: World health organization; PBS: Phosphate buffered saline; LPS: Lipopolysaccharide; RBT: Rose Bengal test.

\section{Acknowledgements}

We wish to thank all of the staff in microbiology departments of Babol University of Medical Sciences and Iran University of Medical Sciences.

\section{Authors' contributions}

RR: Conceptualization and design of the study. AM-Z: Collected the data, cultured the samples, and performed the experimental tests in collaboration with AP, EF-S: Advisor in the study and contributed to the analysis of the data, MG: Contributed to the analysis of the data and wrote /revised of the manuscript in collaboration with AP, FM Assisted in sample collection and SK Performing the statistical analysis of data. All authors read and approved the final manuscript.

\section{Funding}

This work was supported by Babol University of Medical Sciences in Babol, Iran. (Grant No. 9503017).

\section{Availability of data and materials}

All data generated or analyzed during this study are included in this published article.

\section{Ethics approval and consent to participate}

Not applicable.

\section{Consent for publication}

There is no limit to the publication.

\section{Competing interests}

The authors declare no conflict of interest.

\section{Author details}

${ }^{1}$ Department of Microbiology, Faculty of Medicine, Babol University of Medical Sciences, Babol, Iran. ${ }^{2}$ Infectious Diseases and Tropical Medicine Research Center, Babol University of Medical Sciences, Babol, Iran. ${ }^{3}$ Department of Medical Biotechnology, Faculty of Medicine, Babol University of Medical Sciences, Babol, Iran. ${ }^{4}$ Department of Microbiology and Virology, Faculty of Medicine, Mazandaran University of Medical Sciences, Sari, Iran. ${ }^{5}$ Department of Microbiology, Faculty of Medicine, Iran University of Medical Sciences, Tehran, Iran. ${ }^{6}$ Department of Biostatistics and Epidemiology, Faculty of Medicine, Babol University of Medical Sciences, Babol, Iran.

Received: 25 August 2020 Accepted: 5 November 2020

Published online: 13 November 2020

\section{References}

1. Mathew C, Stokstad M, Johansen TB, Klevar S, Mdegela RH, Mwamengele G, Michel P, Escobar L, Fretin D, Godfroid J. First isolation, identification, phenotypic and genotypic characterization of Brucella abortus biovar 3 from dairy cattle in Tanzania. BMC Vet Res. 2015;11(1):1-9.

2. Sofian M, Aghakhani A, Velayati AA, Banifazl M, Eslamifar A, Ramezani A. Risk factors for human brucellosis in Iran: a case-control study. Int J Infect Dis. 2008;12(2):157-61.

3. Young EJ, Corbel MJ. Brucellosis: clinical and laboratory aspects. Boca Raton: CRC Press; 1989

4. Corbel M. International committee on systematic bacteriology subcommittee on the taxonomy of Brucella. Int J Syst Evol Microbiol. 1988;38(4):450-2.

5. Pappas G. The changing Brucella ecology: novel reservoirs, new threats. Int $J$ Antimicrob Agents. 2010;36:58-11.

6. Pappas G, Papadimitriou P, Akritidis N, Christou L, Tsianos EV. The new global map of human brucellosis. Lancet Infect Dis. 2006;6(2):91-9.

7. Rotz LD, Khan AS, Lillibridge SR, Ostroff SM, Hughes JM. Public health assessment of potential biological terrorism agents. Emerg Infect Dis. 2002;8(2):225
8. Alves CJ, Figueiredo SMd, Azevedo SSd, Clementino IJ, Keid LB, Vasconcellos SA, et al. Detection of Brucella ovis in ovine from Paraíba State, in the Northeast region of Brazil. Brazilian J Microbiol. 2010;41(2):365-7.

9. Queipo-Ortuño M, Colmenero J, Reguera J, García-Ordoñez M, Pachón M, Gonzalez M, et al. Rapid diagnosis of human brucellosis by SYBR Green I-based real-time PCR assay and melting curve analysis in serum samples. Clin Microbiol Infect. 2005;11(9):713-8.

10. Lulu A, Araj G, Khateeb M, Mustafa M, Yusuf A, Fenech F. Human brucellosis in Kuwait: a prospective study of 400 cases. QJM Int J Med. 1988:66(1):39-54.

11. Navarro E, Casao MA, Solera J. Diagnosis of human brucellosis using PCR. Expert Rev Mol Diagn. 2004;4(1):115-23.

12. Bricker BJ. PCR as a diagnostic tool for brucellosis. Vet Microbiol. 2002;90(1-4):435-46.

13. Staszkiewicz J, Lewis C, Colville J, Zervos M, Band J. Outbreak of Brucella melitensis among microbiology laboratory workers in a community hospital. J Clin Microbiol. 1991;29(2):287-90.

14. Young EJ. Serologic diagnosis of human brucellosis: analysis of 214 cases by agglutination tests and review of the literature. Rev Infect Dis. 1991;13(3):359-72.

15. Baily G, Krahn J, Drasar B, Stoker N. Detection of Brucella melitensis and Brucella abortus by DNA amplification. Tropical Med Int Health. 1992;95(4):271-5.

16. Herman L, De Ridder H. Identification of Brucella spp. by using the polymerase chain reaction. Appl Environ Microbiol. 1992;58(6):2099-101.

17. Leal-Klevezas DS, Martínez-Vázquez IO, Lopez-Merino A, Martínez-Soriano JP. Single-step PCR for detection of Brucella spp. from blood and milk of infected animals. J Clin Microbiol. 1995:33(12):3087-90.

18. Maurer JJ. Rapid detection and limitations of molecular techniques. Ann Rev Food Sci Technol. 2011:2:259-79.

19. Notomi T, Okayama H, Masubuchi H, Yonekawa T, Watanabe K, Amino N, et al. Loop-mediated isothermal amplification of DNA. Nucleic Acids Res. 2000;28(12):e63-e.

20. Mori Y, Nagamine K, Tomita N, Notomi T. Detection of loop-mediated isothermal amplification reaction by turbidity derived from magnesium pyrophosphate formation. Biochem Biophys Res Commun. 2001:289(1):150-4.

21. Maruyama F, Kenzaka T, Yamaguchi N, Tani K, Nasu M. Detection of bacteria carrying the stx2 gene by in situ loop-mediated isothermal amplification. Appl Environ Microbiol. 2003;69(8):5023-8.

22. Curtis KA, Rudolph DL, Owen SM. Rapid detection of HIV-1 by reversetranscription, loop-mediated isothermal amplification (RT-LAMP). J Virol Methods. 2008;151(2):264-70.

23. Moslemi E, Shahhosseiny MH, Javadi G, Praivar K, Sattari TN, Amini HK. Loop mediated isothermal amplification (LAMP) for rapid detection of HBV in Iran Afr J Microbiol Res. 2009;3(8):439-45.

24. Iwamoto T, Sonobe T, Hayashi K. Loop-mediated isothermal amplification for direct detection of Mycobacterium tuberculosis complex, M. avium, and M. intracellulare in sputum samples. J Clin Microbiol. 2003;41 (6):2616-22.

25. Ohtsuki R, Kawamoto K, Kato Y, Shah M, Ezaki T, Makino SI. Rapid detection of Brucella spp. by the loop-mediated isothermal amplification method. J Appl Microbiol. 2008;104(6):1815-23.

26. Xu N, Wang W, Chen F, Li W, Wang G. ELISA is superior to bacterial culture and agglutination test in the diagnosis of brucellosis in an endemic area in China. BMC Infect Dis. 2020;20(1):11.

27. Young EJ. An overview of human brucellosis. Clin Infect Dis. 1995;21(2):283-9.

28. Weynants V, Tibor A, Denoel PA, Saegerman C, Godfroid J, Thiange P, et al. Infection of cattle with Yersinia enterocolitica O: 9 a cause of the false positive serological reactions in bovine brucellosis diagnostic tests. Vet Microbiol. 1996:48(1-2):101-12.

29. Klietmann WF, Ruoff KL. Bioterrorism: implications for the clinical microbiologist. Clin Microbiol Rev. 2001;14(2):364-81.

\section{Publisher's Note}

Springer Nature remains neutral with regard to jurisdictional claims in published maps and institutional affiliations. 